\title{
A experiência de sucessão para herdeiras de empresas familiares do Rio de Janeiro
}

\section{The experience of succession for women in family firms in the state of Rio de Janeiro}

\author{
Roberta Magalhães da Cruz Machado ${ }^{1}$ \\ Ursula Wetzel \\ Monica Esteves Rodrigues ${ }^{3}$
}

\section{Resumo}

Este artigo uniu dois temas de importância significativa - sucessão familiar e gênero - para a economia brasileira em uma única pesquisa, visando trazer uma contribuição tanto prática quanto acadêmica. Por um lado, esperamos que o maior entendimento por parte das mulheres herdeiras das suas especificidades no processo de sucessão venha a ajudálas a vivenciá-lo com um menor número de conflitos. Por outro, esperamos contribuir para o enriquecimento da literatura brasileira sobre questões de gênero na sucessão dessas empresas familiares, tema ainda muito pouco explorado em nível mundial e que vem sendo apontado por teóricos como uma linha de pesquisa que precisa ser mais aprofundada, à medida que casos de sucessão feminina se tornam mais comuns.

O objetivo da pesquisa foi verificar no ambiente brasileiro como ocorria a preparação para a tomada de poder por essas mulheres, como elas sentiam a criação de sua identidade como potenciais sucessoras e como percebiam as principais questões abordadas pela literatura mundial sobre o tema. Por meio de dados qualitativos, obtidos em entrevistas em profundidade com sete herdeiras de empresas de setores diversos, localizadas na cidade do Rio de Janeiro, foi possível levantar importantes questões ligadas ao estágio inicial da sucessão pela mulher nos negócios familiares. Resultados indicaram a falta de um planejamento antecipado de ingresso na empresa, dificuldade e demora na criação de identidade, angústia pela ausência de perfil empreendedor, perda nas redes sociais de contato, excesso de proteção pelo pai e saudável equilibrio vida/trabalho.

Palavras-chave: empresas familiares; processo sucessório; questões de gênero.

\begin{abstract}
This article combined important subjects for the Brazilian economy seeking to make a practical and theoretical contribution. We hope the better understanding of the succession process by women can help them and their families to prepare for some predictable problems. We also hope to contribute for the enrichment of the Brazilian literature on gender issues in family business as this subject still requires further research, and succession by women becomes a common phenomenon. The objective of this study was to identify how Brazilian women prepared themselves to take over their family's firm, how they perceived their identity as potential successors, and how they perceived the whole process of succession. Data were collected via in-depth interviews with seven female successors of diverse industries located in the city of Rio de Janeiro. Results indicate the lack of preparation to join the company, difficulties in creating an identity, an anxiety for not demonstrating entrepreneur skills, a closure of social connections and excessive protection from fathers. On the positive side, results also indicate that a healthy work-life balance can be achieved during the process.
\end{abstract}

Key words: family firms; succession process; gender issues.

\footnotetext{
${ }^{1}$ Mestre em Administração pelo Instituto de Pós-Graduação e Pesquisa de Administração da Universidade Federal do Rio de Janeiro (COPPEAD/UFRJ). Endereço: Rua Nascimento Silva, 466/ 202 - Ipanema - Rio de Janeiro/RJ - Brasil - 22421020. E-mail: roberta.machado@record.com.br

${ }^{2}$ Professora Adjunta no Instituto de Pós-Graduação e Pesquisa de Administração da Universidade Federal do Rio de Janeiro (COPPEAD-UFRJ). Doutora em Administração pelo Instituto Pós-Graduação e Pesquisa de Administração da Universidade Federal do Rio de Janeiro (COPPEAD-UFRJ); Professora Adjunta da área de Organizações, Estratégia e Sistemas do Instituto Coppead de Administração - UFRJ.Endereço: Rua 36 n. 255 - Cidade Universitária - Rio de Janeiro/RJ Brasil - CEP: 21949900. Email: ursula@coppead.ufrj.br

${ }^{3}$ Professora Horista e Coordenadora Acadêmica do Curso de Formação em Empreendedorismo do Instituto Coppead de Administração. Doutora em Administração pelo COPPEAD-UFRJ. Endereço: Rua Marquês de Olinda, 106/419 - Botafogo - Rio de Janeiro/RJ - Brasil - CEP: 22251040. E-mail: monicar@centroin.com.br
}

Artigo submetido em novembro de 2007 e aceito em fevereiro de 2008 


\section{Introdução}

O modelo familiar de gestão empresarial transfere para a esfera profissional as intensas relações entre membros de uma família, e essa mistura de aspectos emocionais com questões profissionais vem despertando o interesse acadêmico mundial sobre a empresa familiar nas últimas décadas. No Brasil, Bethlem (1999) afirma que o peso dessas empresas é muito alto, o que as faz serem consideradas por muitos estudiosos como o pilar da economia brasileira. De acordo com o autor, o perfil industrial brasileiro ainda se apresenta concentrado nas mãos de poucos indivíduos, principalmente, de grupos familiares, ao contrário do que aponta a tendência norteamericana de pulverização do controle das empresas, que seria decorrente da necessidade crescente de capital de terceiros para financiar o crescimento.

Na literatura sobre empresa familiar, a linha de pesquisa mais popular é a que aborda o processo sucessório. Tanto material acadêmico tem uma explicação: as estatísticas são muito pessimistas no que diz respeito à sobrevivência dessas empresas após a morte da primeira geração de empreendedores. Sabe-se que apenas $24 \%$ das empresas familiares no Reino Unido sobrevivem como tais até a segunda geração, e que somente 14\% conseguem ir além da terceira (LEACH, 1998). Nos EUA, estimativas indicam que 70\% delas são liquidadas ou vendidas após a morte de seus fundadores (LANSBERG, 1988). No Brasil, pesquisas realizadas em 2002 indicavam que, de cada 100 fortunas de famílias brasileiras, apenas 18 foram herdadas (BERNHOEFT; GALLO, 2003).

Por outro lado, poucos estudos sobre sucessão familiar se concentram num importando dado: o aumento do número de mulheres sucessoras. Hoje, cada vez mais, as filhas herdeiras vêm sendo escolhidas para a presidência das empresas da família, em função de uma maior participação feminina em nível de gerência, no mercado de trabalho. Em 2002, 34\% das empresas familiares americanas projetavam mulheres para os cargos de CEO, contra 25\% em 1997 (CHANDLER, 2004). No Brasil, balanço da Catho Consultoria de Recursos Humanos indica que a porcentagem de mulheres no comando das empresas também tem subido nos últimos anos No período entre 2000 e 2001, por exemplo, essa porcentagem era de $13,88 \%$, tendo aumentado para $20,17 \%$ entre 2006 e 2007. O mesmo levantamento mostra que, no caso de empresas com mais de 1,5 mil funcionários, a porcentagem de mulheres na presidência ou em cargo equivalente é de 11,06\%; e em empresas pequenas, com menos de 50 funcionários, essa proporção cresce para 25,12\% (IWAKURA, 2007).

As razões para o crescimento feminino na sucessão em empresas familiares são variadas. Algumas mulheres, que não conseguem promoções em empresas cujos altos cargos são reservados aos homens, têm migrado para firmas menores para se tornarem empreendedoras de primeira ou segunda geração (BARNES, 1988). Outras têm buscado na empresa familiar uma oportunidade de melhor equilíbrio vida/trabalho (CROMIE; SULLIVAN, 1999), e, para um terceiro grupo de mulheres, a entrada na empresa familiar não foi planejada e visou apenas ajudar ou ocupar uma posição que familiares não desejavam (DUMAS, 1998).

Segundo Barbieri (1997), quando questões de gênero são adicionadas ao processo sucessório, a pressão entre os envolvidos aumenta ainda mais. Para o autor, a sucessão por filhas mulheres esbarra em questões específicas que precisam ser mais bem estudadas: o preconceito contra a mulher à frente dos negócios, a busca pelo poder de decisão da herdeira, os conflitos com outros membros da família, o equilíbrio vida/trabalho e o tipo de relacionamento com o fundador, entre outros.

Já no Brasil, as dificuldades enfrentadas por essas mulheres seriam ainda maiores do que as das européias ou norte-americanas, dada a forte formação patriarcal de nossa sociedade. Diante desse quadro, cabe perguntar como as sucessoras potenciais de empresas familiares brasileiras têm percebido sua experiência de sucessão, as principais vantagens e desvantagens de trabalharem em suas empresas, os conflitos com as primeiras gerações e seu equilíbrio vida/trabalho.

Nesse contexto, este estudo justifica-se por unir dois temas de importância significativa para a economia brasileira - o modelo familiar de gestão e a participação feminina no ambiente empresarial - em uma única pesquisa. Com isso, temos a expectativa de que o mesmo possa trazer uma contribuição tanto prática quanto acadêmica. Por um lado, esperamos que o maior entendimento por parte das mulheres herdeiras das suas 
especificidades no processo de sucessão venha a ajudá-las a vivenciá-lo com um menor número de conflitos. Por outro, esperamos contribuir para o enriquecimento da literatura brasileira sobre empresas familiares e, em especial, sobre questões de gênero na sucessão dessas empresas familiares, tema ainda muito pouco explorado em pesquisas tanto em nível internacional quanto nacional.

\section{Empresa familiar e processo sucessório}

Muitos autores consideram que há apenas dois tipos de empresas: familiar e não-familiar. Para Sharma (2004), o problema dessa abordagem bipolar é que, na realidade, existem organizações mais e menos familiares, dependendo do grau de envolvimento da família no dia-a-dia das empresas citadas nas pesquisas.

Astrachan e Shanker (2003 apud SHARMA, 2004) apresentam três linhas de definições operacionais de empresas familiares, presentes nas centenas de artigos publicados sobre o assunto. A primeira delas, mais geral, defende que uma empresa é familiar quando a família detém controle de voto sobre decisões estratégicas. Autores que se guiam por essa definição identificam dessa forma grande parte das corporações internacionais inicialmente fundadas por uma família, como Grupo Ford e a DuPont.

A segunda linha de definição diz que a empresa só deve ser chamada de familiar quando, além do poder de voto, a família se envolve no dia-a-dia de sua administração. Nesse caso, seriam retirados dessa classificação os empreendimentos que já foram profissionalizados, ou seja, que são administrados por um executivo não pertencente à família proprietária. Por último, há a definição mais estreita de que a empresa se torna familiar quando pelo menos duas gerações se envolveram no dia-a-dia dos negócios e já ocorreu alguma sucessão entre gerações na família. Se um fundador não possui herdeiros, ou não pretende colocá-los na gestão da empresa, sua firma não poderia ser chamada de familiar.

Sharma (2004) apresenta ainda uma escala, desenvolvida por Astrachan, Klien e Smyrnios (2002 apud SHARMA, 2004), para determinar a influência familiar nesse tipo de empresa, com o objetivo de encorajar os pesquisadores a se afastarem das definições bipolares, classificando mais adequadamente as pesquisas nesse campo. A escala é formada por três categorias: poder, experiência e cultura. Dependendo do grau que a família atinge nessas categorias, o pesquisador classifica a empresa como de alta ou baixa influência familiar.

No que diz respeito às vantagens e desvantagens de um empreendimento familiar, Longenecker, Moore e Petty (1997) afirmam que, em geral, a conotação de "familiar" é negativa. Como desvantagens, destacam que os vínculos emocionais na empresa familiar se tornam um aspecto crucial do seu desenvolvimento e que as intensas relações entre os membros da família, extrapoladas para o ambiente empresarial, provocam grande impacto em sua estrutura e comportamento. Os autores consideram que é justamente essa mistura de aspectos emocionais com aspectos econômicos e de mercado que preocupa os investidores e estudiosos do tema, especialmente no que diz respeito aos problemas com a sucessão.

Por outro lado, Longenecker, Moore e Petty (1997) afirmam que trabalhar numa empresa familiar tem suas vantagens. Desde muito cedo, os herdeiros têm acesso direto ao presidente da companhia e a informações estratégicas que a maioria dos executivos só vai conhecer quando chegar ao topo. O envolvimento seria intenso e garantiria uma lealdade e dedicação que não seriam encontradas tão facilmente em executivos contratados no mercado, possibilitando ainda deter-se na visão de longo prazo com mais facilidade que os gerentes corporativos que estão sendo julgados pelos resultados anuais. Além disso, em uma empresa familiar torna-se mais fácil preservar o clima do local de trabalho, uma vez que tanto os donos quanto os herdeiros podem demonstrar mais facilmente níveis elevados de preocupação e interesse pelos funcionários do que aqueles encontrados em uma corporação típica.

Por fim, Longenecker, Moore e Petty (1997) destacam o fato de que as empresas de propriedade familiar tendem a enfatizar a qualidade e mantêm a tradição de oferecer qualidade e valor ao consumidor. Essas características são parte de um conjunto de vantagens que essas empresas possuem: a empresa zela pelo nome 
da família e seus clientes são beneficiados pelo tratamento "caseiro"; além disso, como foi citado, ela pode se preocupar mais com o longo prazo, a fim de promover o desenvolvimento e a continuidade do negócio.

No Brasil, devido à grande concentração de micro, pequenas e médias empresas que conservam a estrutura familiar dominante, Bethlem (1999) afirma que a definição de "empresa familiar" está normalmente associada à alta influência da família no seu gerenciamento, uma vez que a grande maioria dos negócios familiares do país detém não apenas a propriedade, mas também a responsabilidade por sua gestão. Portanto, quando se fala desse tipo de empresa no Brasil, referimo-nos à família administrando e passando aos herdeiros os cargos gerenciais mais estratégicos. Dessa forma, a pulverização do controle, que ocorre em praticamente toda empresa familiar norte-americana, não é uma realidade no nosso país. Para o autor, isso talvez se deva ao baixo amadurecimento do mercado de capitais nacional ou ao pequeno mercado consumidor, que inviabiliza o fluxo de investimentos de terceiros nessas empresas.

Entretanto, a questão sucessória é considerada tão importante na literatura que, para alguns estudiosos, ${ }^{1}$ uma empresa só se transforma numa "verdadeira" empresa familiar quando consegue passar o controle para a segunda geração (COSTA, 2005). Isso porque as estatísticas ${ }^{2}$ demonstram que a sucessão é uma questão tipicamente problemática em nível mundial: estima-se que $75 \%$ das empresas familiares estejam sob o comando da primeira geração; $20 \%$ nas mãos dos filhos dos fundadores, segunda geração; e apenas 5\% sob controle das gerações seguintes (LETHBRIDGE, 1997).

Considerando o fato de que uma grande quantidade de negócios foi criada nos 15 anos que se seguiram ao fim da II Guerra Mundial e que, conseqüentemente, um número inédito de empresas familiares de todo o mundo vive hoje o processo da sucessão, essa questão ganha ainda mais relevância. Finalmente, vale ainda destacar que, entre os estudos desenvolvidos sobre o processo sucessório nas empresas familiares, muita crítica tem sido feita a respeito dos entraves postos pelos fundadores à sucessão. Se, por um lado, há muitos estudos que defendem exageradamente o perfil dos fundadores, há também estudos apontando que a semente do insucesso da sucessão se encontraria justamente no líder fundador. Segundo Leach (1998), o medo da morte, a relutância em abdicar do controle e do poder, a incapacidade de escolher entre os filhos, o preconceito contra o planejamento e o medo da perda da identidade empresarial seriam características muito comuns entre fundadores e que dificultariam em muito o processo sucessório.

\section{Questões de gênero em empresas familiares}

O tema das diferenças entre homens e mulheres nos negócios é, para Thiry-Cherques e Pimenta (2003), delicado e merecedor de maior aprofundamento em nível mundial, dado que historicamente os estudos têm se concentrado nos homens, por eles deterem a maioria dos postos de liderança nas organizações e serem os herdeiros indicados para conduzir os negócios de família. Apesar disso, identificam diversos autores ${ }^{3}$ que afirmam existirem diferenças significativas na gestão empresarial relacionadas ao sexo e aos estilos de liderança.

Outros autores (HABERMAN; DANES, 2007; HANDLER, 1994) apontam o estudo do gênero em empresas familiares como uma vertente de pesquisa que também precisaria ser mais aprofundada, visando ajudar mais empresas a sobreviverem à passagem para a próxima geração com um menor número de conflitos. Tal estudo englobaria diversas questões como a dinâmica do gênero entre o fundador e a herdeira e o impacto do gênero nos estágios do processo sucessório.

Nesse ponto, vale destacar que optamos por apresentar a seguir as diversas questões identificadas na literatura, organizadas de acordo com os grandes temas mais significativos encontrados na pesquisa de campo, de forma a facilitar a posterior comparação e análise dos dados coletados. 


\section{A entrada na empresa familiar}

Pesquisa de Élvarez, Sintas e Gonzalvo (2002) mostrou que a tendência educacional da mulher de apresentar mais anos de estudos que os homens está alterando os tipos de sucessão em empresas familiares onde irmãos e irmãs concorrem pelos cargos de alta gerência. Apesar de Cole (1997) ter apontado que as mulheres desempenham cargos de menor importância em negócios familiares, os autores descobriram que as mulheres vêm assumindo posições estratégicas para o futuro da empresa - como marketing, design e tecnologia da informação -, enquanto os homens sucessores ocupariam os cargos mais operacionais, como os de finanças, logística e contabilidade.

Dumas (1998), citando o trabalho de outros autores, identificou que as herdeiras que trabalham em empresas familiares encontram problemas similares aos encarados por mulheres em outros negócios ${ }^{4}$ e que também sofrem com problemas únicos à sua condição, como: conflitos entre papéis e lealdade, relacionamentos com irmãos e parentes e brigas por poder e autoridade ${ }^{5}$. Hollander e Bukowitz (1990 apud DUMAS, 1998) afirmam que os tradicionais papéis da mulher na família acabariam predominando também em sua vida profissional, fazendo-as se sentirem presas a eles e impossibilitadas de desenvolver habilidades extrafamiliares que as tornem bem-sucedidas nos negócios. Dois deles seriam especialmente difíceis de se descartar: a mulher com zelo excessivo e a mulher invisivel.

A mulher com zelo excessivo é descrita pelos autores como aquela que é muito atenciosa e preocupada com o bem-estar daqueles ao seu redor. Nos negócios, esse excesso de zelo feminino apareceria como uma espécie de autoproteção. Muitas delas, intuitivamente, pensam que não deveriam ser tão bem-sucedidas no ambiente de trabalho, porque estariam assim prejudicando seu sucesso como mulher e, conseqüentemente, muitas executivas assumiriam esse perfil para evitar serem percebidas como ambiciosas ou agressivas.

Já o segundo tipo de papel no qual as mulheres tipicamente se vêem presas é o de invisível. Em muitos negócios familiares, elas sentem como se não fossem vistas pelos outros. Para as filhas que trabalham na empresa da família, a invisibilidade significaria serem esquecidas como potenciais sucessoras de seus pais. Como antídoto para a invisibilidade, Hollander e Bukowitz (1990 apud DUMAS, 1998) identificam a autopromoção, na qual irmãs, esposas e filhas teriam que anunciar constantemente seus desejos e sua capacidade de assumir posições hierárquicas mais altas. Entretanto, ressaltam que o problema da autopromoção é que ela é vista socialmente como uma atitude não-feminina, que remete à ambição e à agressividade.

A fuga de atitudes socialmente percebidas como de cunho masculino é confirmada pelo estudo de Freudenberger, Freedheim e Kurtz (1989 apud DUMAS, 1998), indicando que mulheres em negócios familiares não têm certeza de como devem se comportar e demonstram receio de que precisem ser muito masculinas e agressivas para atingir o sucesso. Ainda nesse sentido, Robbins (2000 apud GRZYBOVSKI; BOSCARIN; MIGOTT, 2002) ressalta que as normas grupais e os estereótipos masculinos sobre os líderes parecem anular suas preferências pessoais, de tal forma que abandonam seu estilo feminino nesses cargos e atuam de modo mais autocrático.

Analisando um estudo de Salganicoff ${ }^{6}$ com 91 mulheres, Dumas (1998) descobriu que apenas 27\% esperavam entrar no negócio da família. As razões que elas deram para seu ingresso na empresa incluíam ajudar a família, ocupar uma posição que ninguém queria e insatisfação com outro emprego. Segundo a autora, as mulheres pesquisadas não haviam planejado uma carreira na empresa familiar, entrando no negócio apenas para apoiar a família durante uma crise ou porque suas outras opções eram ainda mais indesejáveis.

Por outro lado, estudo de Hisrich e Fulop (1997 apud DUMAS, 1998) afirma que as empresas familiares oferecem uma variedade de oportunidades para as mulheres, incluindo: a segurança do emprego, o horário de trabalho flexível e o acesso a indústrias geralmente dominadas por homens, como construção civil e indústrias de base. Além disso, as mulheres são duas vezes mais propensas a verem suas filhas como sucessoras potenciais e, portanto, ter mulheres como CEOs de empresas familiares pode também ter um impacto positivo na próxima geração feminina desses empreendimentos. 
Já a partir de suas próprias entrevistas, a autora detectou diversos temas surgidos como estímulo para a decisão das mulheres sucessoras de trabalhar na empresa: conectar seus interesses e treinamentos educacionais, abraçar a oportunidade - especialmente, quando experimentaram dificuldades em outras firmas - e a descoberta de mudanças inesperadas na empresa ou na família que as obrigaram a ajudar no negócio. Para algumas entrevistadas, o fim de seus estudos sinalizou o momento de transição, especialmente, quando os estudos relacionavam-se com a atividade da empresa. Para outras, o negócio da família representava a chance de brilhar e provar suas habilidades, o que não conseguiriam em outros empregos.

Com base em outros estudos, Dumas (1998) identificou algumas diferenças-chave entre as formas como filhos e filhas herdeiros são socializados para a sucessão: havia uma regra implícita de que filhas não poderiam ser sucessoras no empreendimento familiar e, por isso, seriam encorajadas a treinar para outras carreiras, enquanto os filhos seriam estimulados a se tornarem aprendizes na empresa da família ${ }^{7}$; e, quando comparadas com seus irmãos do sexo masculino, as filhas gastariam menos tempo na empresa, desenvolveriam menos qualificações e seriam encorajadas a ingressar no negócio familiar menos freqüentemente ${ }^{8}$.

Estudo de Barnes e Kaftan (1990 apud DUMAS, 1998) ressalta que as filhas enfrentam ainda severos desafios para assumir o comando das empresas da família porque freqüentemente encaram o pessimismo de pais e irmãos, que as vêem como incompetentes ou ignorantes sobre o negócio. Já Barnes (1988) afirma que os pais também colocam maior resistência e pressão sobre as filhas que assumem os negócios do que sobre os filhos.

Confirmando essa visão, Dumas (1998) identificou em sua pesquisa com 702 mulheres no Canadá que, ao assumir o comando do negócio, a maioria delas encontrou problemas variados, desde a dificuldade para entender seu papel no negócio e serem aceitas por clientes e fornecedores até a adaptação às longas horas de trabalho demandadas pela função.

No que diz respeito especificamente ao Brasil, estudo de Curimbaba (2002) focou justamente o aspecto da visibilidade das mulheres no processo de sucessão familiar. Seu objetivo era estudar como as estruturas familiares e de negócio afetavam o grau de visibilidade das filhas no processo sucessório; ou seja, o quanto essas variáveis contribuíam para que as filhas fossem consideradas sucessoras efetivas nas empresas. Entrevistando 12 herdeiras do Sudeste brasileiro, a autora avaliou os dados obtidos com base no modelo tridimensional de Gersick et al (1999 apud CURIMBABA, 2002) que se ancora nos conceitos de: propriedade (quanto poder o herdeiro terá na empresa, número de ações, representatividade no conselho etc.); família (tamanho, idade, estado civil, cultura, valores, influência na educação formal etc.) e negócio (ramo industrial). Como resultado da pesquisa de campo, foram encontrados três grupos flexíveis de herdeiras: as profissionais, as invisíveis e as âncoras.

Herdeiras consideradas profissionais seriam assim classificadas porque encarariam seus cargos de uma forma profissional, vendo-o como qualquer outra posição empresarial no mercado. Ainda que o afastamento da questão pessoal seja positivo para o trabalho, o posicionamento profissional traria efeitos negativos porque afastaria a herdeira de importantes questões políticas, como, por exemplo, da própria estratégia de sucessão. Por outro lado, as herdeiras classificadas como invisiveis sofreriam com grandes estruturas familiares, que podem incluir muitos irmãos mais velhos e mais bem preparados para assumir postos altos na empresa. A participação dessas mulheres invisíveis, em geral, visaria apenas à disseminação de valores femininos nos negócios.

Por último, as herdeiras âncoras seriam pertencentes a famílias em que há apenas descendentes mulheres ou com poucos homens, e em que a responsabilidade de liderar a empresa estaria presente desde a infância. Ainda que bem preparadas, essas herdeiras sofreriam com a angústia da alta responsabilidade de serem bem-sucedidas e da dependência entre sua vida pessoal e sua vida no trabalho.

Utilizando diversos casos em organizações familiares no estado de Goiás, estudo de Macedo et al (2004) sobre inclusão/exclusão da mulher no processo de sucessão familiar detectou que, na maioria dos empreendimentos estudados, houve exclusão da herdeira durante a escolha dos sucessores. Essa exclusão teria ocorrido de várias formas, sendo declarada em alguns casos e dissimulada em outros. Essa dissimulação se deu considerando-se as 
mulheres como candidatas num primeiro momento e, posteriormente, descartando-as; ou recorrendo a um discurso ideológico de que a missão e os objetivos da organização tinham orientação masculina para justificar o descarte dos nomes das candidatas mulheres na decisão final.

Mesmo quando participaram do processo sucessório, filhas e esposas da pesquisa de Macedo et al (2004), geralmente, assumiram funções ligadas a cargos socialmente considerados "femininos" - como posições de diretoria na área de recursos humanos -, reproduzindo, assim, a divisão sexual do trabalho na sociedade. Além disso, percebeu-se que a exclusão continuou a ocorrer na maioria das organizações pesquisadas, mesmo após a mulher assumir o cargo, levando-as a enfrentarem mais dificuldades que os familiares do sexo masculino, inclusive, no desempenho de suas funções.

\section{A relação entre pai e filha}

Outra questão importante nas empresas familiares refere-se aos aspectos afetivos entre pais e filhas. Essa importância, segundo Dumas (1990 apud DUMAS, 1998), dever-se-ia ao fato de que o grau de sucesso de um processo sucessório de pai para filha variaria fortemente segundo o tipo de formação de identidade dessa filha.

A autora menciona a importância da comunhão com os outros na formação da identidade feminina e afirma que, em empresas familiares, os pais supririam o importante papel de mentores de suas filhas, validando seu trabalho e contribuindo para uma boa formação de identidade. Esse seria um processo bem diferente daquele de formação da identidade do filho sucessor, que buscaria justamente a separação do pai, para ter reconhecimento próprio, não ligado diretamente a seu predecessor.

Ainda de acordo com a autora, quando as mulheres não criam uma forte identidade própria, tendem a ficar apenas com o papel de "protetoras do pai", cuja função seria unicamente apoiá-lo no dia-a-dia da empresa. O outro extremo ocorreria quando a formação da identidade fosse tão forte que a filha desejasse a separação dos interesses do pai, agindo apenas segundo seus próprios objetivos. O papel desempenhado por esse tipo de sucessora se chamaria "protetora do ouro", uma vez que ela estaria mais interessada em proteger o dinheiro da família do que em agradar o pai. A autora defende, por fim, o papel de "protetora do ouro do rei", uma espécie de posição mediana, em que tanto os objetivos financeiros e mais frios dos negócios quanto os afetivos, de uma aceitação pelo pai, seriam visados.

Para Vera e Dean (2005), o relacionamento entre pai e filha também poderia ser afetado por um conflito de papéis. O pai poderia falhar na definição do papel da filha na empresa, tendo a expectativa de que ela se comporte como uma mulher de negócios, mesmo que simultaneamente a veja, e talvez a trate, apenas como a "filhinha do papai". Essa multiplicidade de papéis pode confundir a filha, que não saberá quando agir como uma funcionária e quando agir como uma filha, gerando tensão entre as duas partes e dificultando a formação de sua identidade própria. No entanto, ainda de acordo com os autores, algumas características femininas como ver o pai como mentor, estar preocupada tanto com ele quanto com seu negócio, manter uma boa comunicação com ele e tender a evitar conflitos - podem ajudar a suavizar os aspectos dolorosos de uma transição sucessória; características essas que, no entanto, se levadas ao extremo, podem ser prejudiciais.

Já Hollander e Bukowitz (1990 apud DUMAS, 1998) notaram que a tendência feminina de evitar conflitos pode atrapalhar quando as filhas preferem não discutir o processo sucessório com o pai por medo de magoá-lo. Essa falta de comunicação pode ainda ser agravada por pais que, ao superprotegerem suas filhas, evitam colocá-las na "linha de fogo". Alguns deles experimentam emoções conflitantes quando pensam em colocar suas filhas como suas sucessoras. Uma vez que comandar um negócio pode ser uma tarefa desgastante e irritante, eles geralmente preferem preservá-las das adversidades da vida. Entretanto, a forma como fazem isso normalmente difere do modo como protegem seus filhos.

\section{A relação entre mãe e filha e outros membros da familia}

O papel desempenhado pelos chamados membros invisíveis da família nos processos sucessórios é também um interessante tema de estudo. Donovan e Bradt (1990) pesquisaram o poder das mulheres invisíveis, 
normalmente, as esposas dos CEOs e mãe dos sucessores. Ainda que o estudo tenha especificamente se voltado para o papel da mulher invisível, as autoras concluem que a preocupação com a influência das opiniões de membros da família que não trabalham oficialmente na empresa também se mostraria importante, independente do gênero dessas pessoas. A justificativa para isso estaria ancorada na teoria de sistemas familiares, que considera todos os integrantes de um sistema reais participantes.

Segundo as autoras, a influência dos membros invisíveis é tão forte que precisa ser levada em consideração por consultores e demais estudiosos de empresas familiares. Decisões importantes são tomadas depois de consultálos e coalizões familiares são montadas com o seu apoio. Enfim, entender o papel das esposas, dos maridos e dos irmãos de CEOs é essencial para se compreender a dinâmica da empresa familiar.

Essa importância dos membros invisíveis da família é claramente identificada na pesquisa de Dumas (1998), realizada com 702 mulheres no Canadá. Se, por um lado, a pesquisa demonstrou que a maioria das mulheres entrevistadas encontrou problemas variados ao assumir o comando do negócio da família; por outro, detectou que, para muitas, o suporte da família teria cumprido papel essencial de apoio moral, de solidariedade e amor. Tal suporte serviria também para perpetuar valores familiares, como honestidade, justiça e alegria.

Quando o pai é o chefe-proprietário, pesquisas de Vera e Dean (2005) sugerem que a mãe que não possui uma posição na empresa pode sentir-se ameaçada pela participação da filha no negócio da família, em função de um relacionamento profissional íntimo do mesmo com a filha, e que essa nova proximidade pode resultar num triângulo entre mãe, pai e filha. Hollander e Bukowitz (1990 apud DUMAS, 1998) sugerem que, se há ciúme por parte da mãe, a filha pode criar conflitos com sua própria "feminilidade", evitando a maternidade e focando mais seu papel de mulher de negócios.

Pesquisa de Dumas (1998) mostrou que existe uma diferença de status entre esposas e filhas em empresas familiares, medida pelo tipo de atividade desempenhada e pelos direitos de propriedade. Enquanto 57,5\% das filhas entrevistadas estavam ativamente envolvidas na companhia, tinham direitos de propriedade e desempenhavam cargos na alta gerência, apenas $42,5 \%$ das esposas encontravam-se na mesma situação.

Finalmente, no que diz respeito especificamente ao relacionamento entre mãe e filha quando a mãe faz parte do negócio, Vera e Dean (2005) afirmam que poucas pesquisas analisaram esse aspecto. Resnick (1994 apud VERA; DEAN, 2005), por exemplo, sugere que, se houver problemas de confiança não resolvidos noa adolescência, quando as duas trabalham juntas, a mãe seria muito controladora e a filha muito crítica em relação à mãe.

\section{Os laços sociais}

No que diz respeito à rede de contatos, Lyman (1988) afirma que, se por um lado, o apoio da família traz conforto para a mulher que trabalha em empresa familiar; por outro, ela sofre uma perda em sua rede de contatos. Em sua pesquisa, o autor concluiu que as mulheres que trabalhavam em empreendimentos familiares viviam em grupos de redes de contatos muito fechados e ligados apenas à família, sendo comum a sobreposição de relacionamentos pessoais e profissionais. Já para as mulheres que trabalhavam em outras firmas, essas redes de contatos eram significativamente maiores e o padrão de interação com os integrantes dessas redes refletia relacionamentos pessoais, profissionais e pessoais-profissionais mais balanceados.

Muitas das mulheres entrevistadas por Lyman (1988) descreveram os custos de estarem associadas a redes de contatos sociais muito homogêneas, nas quais o relacionamento que viviam com pessoas de fora da família era mínimo. Entre eles, destacava-se o de não possuir ou não utilizar inteiramente os laços de amizades para lhe abrirem campos de escolha profissional ou mesmo para escaparem das pressões familiares.

Segundo a autora, essa limitação nas redes de contato tende a restringir a diversidade de comportamentos da mulher que trabalha em sua empresa familiar, reforçando a estabilidade e a previsibilidade de suas interações no ambiente de trabalho, o que poderia ser prejudicial para os negócios num ambiente competitivo e dinâmico. 


\section{A administração feminina versus masculina}

Diversos autores afirmam que a gestão empresarial apresenta diferenças significativas quando aferida em relação a gênero e a estilo de liderança. Para Lodi (1999 apud GRZYBOVSKI; BOSCARIN; MIGOTT, 2002), as mulheres executivas tendem a adotar um estilo de liderança mais democrático, ao passo que os homens se sentem mais à vontade com um estilo diretivo de comando e controle. As mulheres encorajam a participação, a partilha do poder e da informação, tentando aumentar a auto-estima dos seguidores; preferem liderar pela inclusão, recorrendo a seu carisma, à experiência, aos contatos e às habilidades interpessoais para influenciar os outros. Já os homens recorrem à autoridade formal de seu cargo como base para sua influência. Por fim, os autores destacam que a tendência das lideranças do sexo feminino serem mais democráticas que as do sexo masculino diminui quando aquelas ocupam cargos de dominância masculina.

Gelin (1998) apresenta como características consideradas masculinas o espírito competitivo, a independência, a decisão e a autoconfiança; e como características consideradas femininas, a emotividade, a sociabilidade, a compreensão, o cuidado e o carinho. Por outro lado, estudo feito por Fagenson (1990 apud GELIN, 1998) identifica que tem sido dado um maior peso às características masculinas para o perfil de empreendedor de sucesso, o que significa dizer que o papel do gerente - que é visto como independente, persistente, energético, autoconfiante e decisivo - tem sido estereotipado como masculino.

Dentre os fatores morais considerados estratégicos para as empresas, pesquisa de Thiry-Cherques e Pimenta (2003) identifica maior preocupação dos homens com relação à honestidade e à rentabilidade, enquanto as mulheres estão mais preocupadas com a responsabilidade. Dados da mesma pesquisa também apontam outras diferenças significativas, como o fato de as mulheres adotarem atitude mais cautelosa e preventiva e de os homens, em geral, estarem mais voltados para os princípios que orientam os seus atos - as mulheres, para as conseqüências desses atos -, além de mais preocupados com a exteriorização (inclusive, com a aparência) do que com o que é interior e subjetivo.

Num estudo com 23 membros de empresas familiares, Cole (1997) descobriu alguns temas relacionados a questões de gênero e liderança, como a invisibilidade da mulher nessas empresas - onde a capacitação profissional feminina é ignorada - e processos decisórios distintos, nos quais as mulheres levariam mais tempo do que os homens para tomar decisões. Além disso, observou diferentes preocupações, como as relacionadas com o adequado cuidado com os filhos pequenos e com a dupla jornada de trabalho, em casa e na empresa.

No Brasil, Grzybovski, Boscarin e Migott (2002) analisaram o estilo de gerenciamento da mulher executiva nas empresas familiares de Passo Fundo (RS). O objetivo foi identificar esse estilo feminino em empresas familiares, correlacionando-o ao perfil das mulheres gerentes. Foram investigadas 26 executivas, por meio de questionário exploratório e de entrevista semi-estruturada. Ficou evidenciado que as executivas dessas empresas familiares apresentavam um estilo de liderança mais voltado para as pessoas do que para as tarefas, mas que eram muito orientadas para o poder, assumindo postura gerencial mais baseada no modelo masculino de gestão. A pesquisa identificou ainda que essas executivas cultivavam valores como a honestidade, a estima do ser humano e o companheirismo; que permaneciam atuando por amor à empresa da família e que seus desejos e/ou sonhos pessoais estariam relacionados aos sonhos e/ou desejos empresariais.

\section{A questão do equilíbrio vida/trabalho}

Questões de equilíbrio entre vida e trabalho tornaram-se muito populares nas últimas décadas, uma vez que a incompatibilidade entre a dedicação à família e ao trabalho pode gerar uma grande angústia e insatisfação no trabalhador. Se, por um lado, a interferência da vida profissional pode afetar negativamente as relações familiares, por outro, a interferência excessiva da vida familiar de um funcionário, certamente, afeta seu desempenho na empresa. O equilíbrio entre essas duas esferas, a familiar e a profissional, é bastante delicado e importante para empregado e empregador. 
Greehaus e Beutell (1985) definiram o conflito entre trabalho e família como resultado de pressões incompatíveis advindas do exercício simultâneo desses dois papéis. Pesquisas anteriores identificaram dois tipos dominantes de conflito entre trabalho e família: o baseado no tempo e o baseado na tensão. O primeiro tipo de conflito é experimentado quando o tempo despendido no exercício de um papel torna difícil preencher as demandas do outro. O segundo tipo ocorre quando as tensões geradas por um papel invadem o outro. Assim, sintomas como irritabilidade, fadiga e depressão, sentidos em um dos papéis, podem tornar difícil assumir efetivamente o outro.

Quando se trata de mulheres, Teixeira (2005) ressalta que o equilíbrio entre a vida pessoal e a profissional é ainda mais importante. Mesmo com todos os avanços que conquistou nas últimas décadas, as principais funções domésticas ainda são de sua responsabilidade, assim como a criação dos filhos e, em especial, o cuidado com idosos, exigindo muito tempo e dedicação. A conclusão final do autor é de que, para a mulher, há evidentemente uma dificuldade em separar casa/fábrica ou vida pública/privada.

Uma vez que as mulheres que estão empregadas continuam a fazer a maior parte do trabalho da casa, independentemente de seu status, de suas horas de trabalho ou de sua remuneração, as experiências profissionais femininas têm características específicas, que devem ser levadas em conta ao se analisar a questão do equilíbrio entre vida profissional e vida pessoal. Assim, um ponto naturalmente valorizado pelas mulheres é a possibilidade de flexibilizar as horas e os locais de trabalho. Um estudo de Hill et al (2001) comparou funcionários com a mesma carga de trabalho e concluiu: que aqueles que tinham flexibilidade de local e carga horária apresentavam um melhor equilíbrio entre vida e trabalho; e que funcionários com um bom equilíbrio conseguiam trabalhar por mais horas, antes que a carga de trabalho influenciasse negativamente sua vida pessoal.

Nessa mesma linha, a pesquisa de Scandura e Lankau (1998) revelou que as mulheres que percebiam nas organizações onde trabalhavam a disponibilização do horário de trabalho flexível apresentavam maior comprometimento organizacional e maior satisfação no trabalho do que mulheres sem horário flexível. Pesquisa similar de Hill et al (2004) avaliou os benefícios do trabalho em horário parcial para mulheres com filhos em idade pré-escolar nos EUA. Os resultados apontaram uma maior percepção de sucesso familiar, satisfação com cuidados da criança e melhor equilíbrio entre vida e trabalho entre mulheres com dedicação parcial quando comparadas àquelas com dedicação integral.

A diferença entre os negócios familiares e os não-familiares parece se refletir na forma como dinheiro, posições e tempo são alocados. Enquanto a maioria das empresas toma decisões baseadas em lucratividade, os empreendimentos familiares permitem que dimensões pessoais sejam levadas em conta. Esse fato é particularmente importante para as mulheres, preocupadas em balancear aspectos pessoais e profissionais (COLE, 1997).

A consciência da importância de um maior equilíbrio entre vida pessoal e profissional para as mulheres tem alterado, inclusive, os contratos de trabalho - mesmo os informais -, já que a relação entre empresa e empregado transcende o contrato formal. Segundo Rousseau (1995), existe um contrato psicológico no qual cada uma das partes imagina quais serão seus direitos e deveres em relação à outra. Essa teoria sugere que mulheres e aqueles com responsabilidades familiares devem negociar novos contratos psicológicos que incluam benefícios voltados à família, como horário de trabalho flexível.

Trabalhar na empresa de propriedade familiar poderia representar um caminho para essa conciliação. Se o diretor-proprietário é da família da mulher sucessora - normalmente, seu pai ou avô -, seria natural que ele compreendesse e permitisse uma flexibilidade de horário que a possibilite atender de forma mais equilibrada às suas demandas, tanto de caráter pessoal quanto profissional. Essa possibilidade de melhor equilibrar atividades profissionais com vida familiar tem se mostrado um importante motivador para o ingresso da mulher na empresa de sua família, conforme apontado pela pesquisa de Cromie e Sullivan (1999), na qual um percentual considerável de entrevistadas respondeu que essa opção se dera em função da possibilidade de conciliação de tarefas profissionais e domésticas. Um terço dessas mulheres citou ainda a importância de cuidarem de filhos pequenos enquanto trabalhavam. 
Entretanto, o sucesso de atingir um saudável equilíbrio entre vida pessoal e profissional na empresa familiar é ainda controverso. De acordo com pesquisa de Cadieux, Lorrain e Hugron (2002 apud VERA; DEAN, 2005), filhas em negócios familiares tendem a trabalhar aproximadamente 70 horas semanais, enquanto mulheres que trabalham mais de 45 horas por semana reportam conflitos para gerenciar vida doméstica e vida profissional. Portanto, trabalhar longas horas pode privar a mulher de cuidar de uma família, o que pode gerar dúvidas quanto a sua própria identidade e frustar as expectativas da sociedade.

\section{Aspectos metodológicos}

Este estudo segue o paradigma construtivista (CRESWELL, 2003). Suas premissas ontológicas, portanto, baseiam-se no relativismo, segundo o qual as múltiplas realidades são concepções mentais e sociais vistas apenas dentro de um contexto. No construtivismo, o pesquisador e o pesquisado formam um todo e o resultado do estudo é conseqüência, justamente, desse processo de interação. Acredita-se que apenas uma posição subjetiva pode apreender a realidade e, portanto, pouca atenção é dada a vieses no processo de pesquisa, ao contrário dos pós-positivistas.

Quanto à estratégia de pesquisa, a classificação que se mostrou mais adequada a esse trabalho foi o estudo de casos. Essa estratégia permite não apenas avaliar situações familiares e organizacionais em seus contextos originários, mas também analisar como se manifestam e evoluem ao longo do tempo. Além disso, facilita ao pesquisador um conhecimento mais próximo das ações individuais, permitindo também captar padrões de interação recorrentes, que explicitam as especificidades da dinâmica sociocultural dessas organizações (DAVEL; COLBARI, 2003).

Por último, ancorado em um corpo teórico mais ou menos explícito, o método da pesquisa conduz a busca do material empírico e define os procedimentos de organização e de análise dos dados, de maneira a inserir a pesquisa de campo no enquadramento conceitual delimitado no projeto. Segundo Davel e Colbari (2003), se o objetivo é compreender os fenômenos socioculturais constituintes da dinâmica dos empreendimentos familiares, a metodologia qualitativa da pesquisa, em decorrência de seu caráter circular e reflexivo, é mais adequada à apreensão de tais fenômenos. Isso porque, para compreender os processos socioculturais de organizações familiares, não basta verificar a freqüência de aparição de fenômenos ou outras modalidades de mensuração que privilegiem aspectos quantitativos; a profundidade das análises conta mais do que a multiplicação de casos.

Com o objetivo de analisar as percepções de sucessoras de empresas familiares sobre questões relativas ao estágio inicial da sucessão, foram definidos como sujeitos da pesquisa: mulheres jovens (menos de 35 anos), residentes no Rio de Janeiro, que ingressaram há mais de um ano e há menos de 10 na empresa de propriedade da família, mas que ainda não sucederam totalmente a geração anterior na plena gestão da empresa. Tais mulheres trabalhavam integralmente na empresa de suas famílias até a data das entrevistas e não tinham outra profissão a que se dedicassem. Algumas das entrevistadas eram as únicas sucessoras potenciais do negócio, enquanto outras possuíam irmãos ou primos trabalhando em conjunto. Algumas mulheres pertenciam à terceira geração, embora a maioria estivesse na segunda geração de familiares no poder.

Em princípio, não foi definido um número ideal de entrevistas. No entanto, devido às limitações de tempo e ao perfil bastante específico das herdeiras (idade reduzida, estágio inicial de sucessão, empresas no Rio de Janeiro), foram feitas sete entrevistas em profundidade. A saturação teórica, situação indicativa de repetição das questões conceituais, não chegou a ser assegurada devido ao número limitado de entrevistas. No entanto, alguns aspectos emergiram com razoável consistência nos resultados da pesquisa.

Com relação aos setores do negócio, as sete entrevistadas são herdeiras de empresas de diferentes ramos: fabricante de vidros para indústria médica, editora de livros, distribuidora de pescados para restaurantes, fabricante de estruturas metálicas para galpões, comércio de tintas industriais, usina de álcool e açúcar e cerimonial para eventos e casamentos. 
A seleção das pesquisadas foi feita por conveniência, respeitando-se o perfil predefinido, ainda que se tenha tomado cuidados, como o de distribuir as entrevistadas por ramos de diferentes atividades. É importante ainda ressaltar que a maioria das mulheres ouvidas provém da Região Metropolitana do Rio de Janeiro e possui um alto nível de renda e de educação formal.

Um breve perfil das empresas e das entrevistadas é apresentado no quadro 1.

\section{Quadro 1 - Empresas e entrevistadas}

\section{E1: Fábrica de produtos de vidro utilizados pela indústria médica (tubos de ensaio, pipetas etc.)}

\begin{tabular}{ll}
\hline Fundação & Fundada pelo pai da entrevistada na década de 1960. \\
\hline Sócios & $\begin{array}{l}\text { Inicialmente, dividia a propriedade e a gestão da firma com um sócio, mas a incompatibilidade } \\
\text { de idéias e planos para o crescimento da empresa fez com que rompessem a sociedade. }\end{array}$ \\
\hline Sucessão & $\begin{array}{l}\text { A esposa é contratada para cuidar da área financeira, mas sempre contou com a filha para ser sua } \\
\text { sucessora, a qual já demonstrava interesse em trabalhar na firma desde bastante jovem. Seu } \\
\text { outro filho optou pela carreira médica. }\end{array}$ \\
\hline Entrevistada & $\begin{array}{l}\text { Escolheu estudar economia para preparar-se para a sucessão na empresa; iniciou estágio com } \\
\text { seus pais antes mesmo de iniciar as aulas e, desde então, trabalha na empresa e se prepara para } \\
\text { assumir o controle quando seus pais se aposentarem. Tem 30 anos, é casada e não tem filhos. }\end{array}$
\end{tabular}

\section{E2: Editora de livros}

Fundação Fundada pelo avô de nossa entrevistada, self-made man que estudou apenas até a $4^{\mathrm{a}}$ série primária e conseguiu publicar o primeiro livro da editora em 1956.

Até 1973, trabalhou com seus dois irmãos como sócios, tanto na editora, como nas duas livrarias

Sócios da família. Quando os irmãos se desentenderam e resolveram dividir o negócio, o avô ficou com a editora e cada um dos outros assumiu a propriedade de uma livraria.

Sucessão se afastando do trabalho, seus filhos foram mudando um pouco o perfil dos livros editados e modernizando a editora. Atualmente, divide as responsabilidades da editora com seu tio, sua prima e sua mãe.

Entrou na empresa em 1990, de forma inesperada, quando seu avô sofreu um infarto. Na

Entrevistada ocasião, estudava design e tinha outros planos para sua carreira; mas apaixonou-se pelo negócio da família. Tem 33 anos, é separada e tem duas filhas pequenas.

\section{E3: Distribuidora de pescados para restaurantes, hotéis e indústrias}

\begin{tabular}{ll}
\hline Fundação & Fundada há aproximadamente 25 anos pelo pai da entrevistada. \\
\hline Sócios & Não tem. Imigrante italiano, começou fazendo todo o trabalho sozinho. \\
\hline Sucessão & $\begin{array}{l}\text { De origem humilde e muito ligado à família, o fundador levou seus três filhos para trabalhar na } \\
\text { empresa Quando estavam formados. Mas, apesar de possuir primos trabalhando na empresa, } \\
\text { apenas ela e seus dois irmãos são cotados para a sucessão. }\end{array}$ \\
\hline Entrevistada & $\begin{array}{l}\text { É a filha do meio, tem } 29 \text { anos e é solteira. Estudou economia por acreditar ser um curso útil às } \\
\text { demandas da empresa e por ser uma área acadêmica complementar ao curso de administração, } \\
\text { escolhido por seu irmão mais velho. }\end{array}$
\end{tabular}

\section{E4: Fábrica de estruturas metálicas para galpões}

Fundação Criada em 1978 pelo pai da entrevistada. Desenvolveu uma tecnologia de cobertura metálica que foi patenteada e exportada para diversos países.

Sócios Por se tratar de uma tecnologia nova no mercado, o fundador passou por um período inicial duro e precisou chamar seus dois cunhados para ajudarem na empresa.

Sucessão Além dos tios, tem uma irmã trabalhando na empresa e outra se preparando para ingressar nos negócios, embora tenda a ser a sucessora natural do pai, por ser a mais velha das três filhas do fundador.

Estudou engenharia civil e engenharia de produção e começou na empresa há aproximadamente

Entrevistada seis anos, tão logo se graduou, após ter buscado sem sucesso uma experiência em outra empresa para fortalecer sua bagagem profissional. Preocupada com isso, sempre buscou se aperfeiçoar através de cursos de pós-graduação. Tem 29 anos, é casada e não tem filhos. 


\begin{tabular}{|c|c|}
\hline \multicolumn{2}{|c|}{ E5: Comércio de tintas industriais (revendedora de uma multinacional) } \\
\hline Fundação & $\begin{array}{l}\text { Fundada há aproximadamente oito anos pelo pai da entrevistada, uma pessoa de origem simples } \\
\text { que trabalhou na multinacional que hoje representa. }\end{array}$ \\
\hline Sócios & Não tem. \\
\hline Sucessão & Conta com seu irmão para apoiá-la nas funções da empresa, mas tende a ser a sucessora do pai. \\
\hline Entrevistada & $\begin{array}{l}\text { Estudou marketing, mas dedicou-se primordialmente à dança, sua verdadeira paixão. Após } \\
\text { curtos estágios na área de marketing, entrou na empresa por um pedido do pai que precisava de } \\
\text { alguém para substituir uma funcionária afastada por razões médicas. Tem } 28 \text { anos, é solteira, } \\
\text { sem filhos e mora com seus pais. }\end{array}$ \\
\hline \multicolumn{2}{|c|}{ E6: Usina de álcool e açúcar } \\
\hline Fundação & $\begin{array}{l}\text { Fundada em } 1975 \text { pelo avô da entrevistada. Foi uma importante destilaria de álcool no estado do } \\
\text { Maranhão durante o período do Pró-Álcool. Funcionou por } 15 \text { anos, mas a desaceleração do } \\
\text { mercado de etanol ocorrida no fim dos anos } 1980 \text { acabou causando a falência e conseqüente } \\
\text { fechamento da empresa. }\end{array}$ \\
\hline Sócios & Foi reaberta recentemente em sociedade com um fundo americano de private equity. \\
\hline Sucessão & $\begin{array}{l}\text { Apesar de funcionar no interior do Maranhão, todo o controle operacional da firma é feito do } \\
\text { escritório do Rio de Janeiro, com a ajuda da entrevistada, de sua irmã advogada e, } \\
\text { posteriormente, de seu irmão. }\end{array}$ \\
\hline Entrevistada & $\begin{array}{l}\text { Tem } 32 \text { anos, é solteira, não tem filhos e mora com a mãe e os irmãos. Trabalhou muitos anos } \\
\text { na Rede Globo e ainda tem experiência em bancos de investimentos e cursos de pós-graduação. }\end{array}$ \\
\hline \multicolumn{2}{|c|}{ E7: Prestadora de serviços e aluguel de material para eventos e casamentos } \\
\hline Fundação & Fundada há 10 anos pela mãe da entrevistada. \\
\hline Sócios & $\begin{array}{l}\text { Composta por três gerações de empresárias: a avó, estilista de noivas há } 55 \text { anos; sua filha, que } \\
\text { montou a firma; e suas duas netas, que hoje conduzem a empresa. }\end{array}$ \\
\hline Sucessão & $\begin{array}{l}\text { A entrevistada enfrenta alguns conflitos com as gerações superiores para concretizar seus } \\
\text { projetos. }\end{array}$ \\
\hline Entrevistada & $\begin{array}{l}\text { Após uma experiência profissional na Europa, onde participou de vários trabalhos ligados à área } \\
\text { de eventos, a entrevistada juntou-se à mãe e à avó apenas depois de concluir um curso de moda } \\
\text { e testar por alguns anos o mercado de confecções. Tem } 31 \text { anos, é casada e tem uma filha } \\
\text { pequena. }\end{array}$ \\
\hline
\end{tabular}

Fonte: MACHADO, Roberta Magalhães da Cruz. Pesquisa de Campo para Dissertação de Mestrado. Rio de Janeiro: Coppead/UFRJ, 2006.

\section{Descrição e análise dos resultados}

A partir da análise das entrevistas e visando facilitar a compreensão da interpretação, os pontos de conteúdo mais significativo foram organizados em grandes temas, incluindo, por vezes, trechos dos discursos das herdeiras. Suas falas foram fielmente reproduzidas e eventuais erros gramaticais foram mantidos para preservar a naturalidade dos relatos.

É importante lembrar novamente que os temas, embora apresentados separadamente para facilitar o entendimento, na prática, estão entrelaçados. Os principais tópicos identificados foram: (1) a entrada na empresa familiar; (2) a relação pai e filha/o pai mentor; (3) o papel dos membros invisíveis da família/a relação mãe e filha; (4) perda de contatos sociais/tipos de laços sociais; (5) administração feminina $x$ administração masculina e (6) equilíbrio vida/trabalho.

\section{A entrada na empresa familiar}

O ingresso das entrevistadas nas empresas da família parece confirmar a tendência encontrada na literatura de ausência de um planejamento formal de carreira na empresa familiar, onde os principais motivos para entrada no negócio seriam o de ajudar a família a passar por uma crise ou porque as outras opções eram ainda mais 
indesejáveis (SALGANICOFF, 1990 apud DUMAS, 1998). A entrada para ajudar em uma crise específica apareceu claramente em duas entrevistas:

Em 90, foi a primeira operação de coração do meu avô. Então, eu comecei a trabalhar indo para a Bienal. Mas, tipo assim, eu nunca imaginei [que trabalharia na empresa familiar]... Eu fui fazer museologia no começo e achava que eu ia trabalhar com arte, com restauração. (E2)

Nossa gerente... teve que sair para fazer uma cirurgia. Então, eu entrei lá mais por necessidade; eu não visava isso. (E5)

Apenas duas entrevistadas entraram na empresa da família porque sempre sonharam e planejaram isso. Mesmo entre aquelas cujas empresas não passavam por crises no momento da decisão de sua entrada, o motivo de ingresso aponta para a falta de opção mais atrativa, destacando-se na escolha pelo negócio familiar a conveniência e a afetividade.

Eu tinha aquela coisa de adolescente: "quero ter a minha vida", "quero conseguir tudo sozinha", mas depois... Eu atendia muita família em que os filhos tomavam conta do negócio dos pais. E eu comecei a ver que era muito mais fácil [trabalhar em empresa herdada pela família]. (E7)

Durante a faculdade, eu trabalhei como arquiteta e, depois, eu fui trabalhar numa obra de construção civil mesmo. E depois eu larguei para procurar alguma coisa mais séria para ver se eu podia sair da faculdade e ser efetivada... Mas não consegui. Me formei no dia, sei lá, 10; e no dia 11 eu estava aqui dentro. (E4)

Ele [meu pai] sempre achou que cada um tinha que seguir seu próprio caminho para depois vir conhecer. E acabou que, nesse meio tempo, as empresas fecharam e eu acabei indo para o banco... E depois, quando eu saí da Globo e estava indo para a Embratel, meu pai falou: você não quer vir trabalhar comigo? (E6)

Mais uma vez confirmando a literatura, a entrada na empresa de forma repentina, sem um planejamento antecipado, pareceu gerar nas mulheres uma dificuldade de entender seu papel no negócio e de criar uma identidade clara naquele ambiente (DUMAS, 1998; VERA; DEAN, 2005). Uma primeira interpretação, mais otimista, seria a de que, talvez fugindo do papel autoritário, os proprietários das empresas não forçariam o ingresso das filhas no negócio. Possivelmente, para deixá-las mais livres em todo o processo de sucessão, evitariam também formalizar um plano de entrada, conversar sobre o assunto, planejar cargos e metas. Algumas queixas da ausência dessa conversa mais formal sobre o plano de carreira delas apareceram nas entrevistas.

Meu pai, por ele ser dono de empresa, ele se afastou muito do dia-a-dia do empregado, e eu achei que ele não percebeu as dificuldades que eu teria ao entrar... Eu acho que eu tentaria dar mais suporte nesse começo. Acho que eu falaria mais em casa sobre o assunto do que eles falaram comigo; seria mais explícita nas minhas vontades. Mesmo que possa ser mais pressão, eu preferiria fazer isso desse jeito... Apesar de, no fundo, eu saber que ele imaginava que eu estaria aqui, ele não se preparou também. Mas no dia que eu vim, eu disse: "e aí, o que você vai fazer comigo?” Aí, ele teve que me dar um destino, me colocou para trabalhar na área de produção. (E4)

Como uma interpretação alternativa, poderíamos sugerir que o dono da empresa simplesmente nunca tivesse considerado a filha capaz de comandar o negócio no futuro, configurando o típico problema da invisibilidade da herdeira no processo de sucessão identificado em diversos estudos acadêmicos (CURIMBADA, 2002; DUMAS, 1998; MACEDO et al, 2004). Levando em conta o fato de que as filhas freqüentemente encaravam o pessimismo de pais e irmãos - que as veriam como incompetentes ou ignorantes sobre o negócio -, poderíamos identificar nessa falta de planejamento antecipado da entrada da filha na empresa familiar um preconceito de gênero por parte dos pais ou mães fundadores. 
Utilizando a classificação das herdeiras desenvolvida por Curimbaba (2002), a maior parte das nossas entrevistadas poderia ser classificada no grupo das herdeiras âncoras, já que pertencem a famílias em que há apenas descendentes mulheres (E2, E4 e E7) ou com poucos homens (E1, E3 e E5), e em que a responsabilidade de liderar a empresa esteve presente desde a infância (E1, E3, E4 e E6). Além disso, mesmo bem preparadas, todas essas herdeiras afirmaram sentir-se angustiadas diante da responsabilidade de serem bem-sucedidas, mas estarem ao mesmo tempo divididas entre a vida pessoal e o trabalho.

Mesmo classificadas como âncoras, a maior parte das entrevistadas não planejou a entrada na empresa; ou seja, o fato de serem âncoras não foi determinante para que tivessem uma conversa mais formal sobre o assunto com os fundadores. A angústia da entrada repentina pareceu menor nos casos em que a mulher já vinha sendo exposta ao "mundo da empresa", sofrendo uma socialização gradativa.

Começar na empresa foi muito antes de começar a trabalhar. Quando entrei na faculdade, eu já tinha a intenção de ir para lá porque aquilo já fazia parte da minha vida, já era muito natural. Já conhecia os clientes, os produtos, a maneira do meu pai trabalhar, como a empresa caminhava; tudo a gente já sabia... Não senti pressão, mas não houve uma decisão pontual de trabalhar lá. Como eu sempre fui muito para lá, meu pai ficava: "e aí, vai querer fazer o quê?”, e eu dizia "não sei”. Mas eu ia, e eu fui me agregando e, de repente, eu já estava lá dentro. (E3)

De fato, a literatura aponta para a importância de uma socialização prévia na empresa como forma de atenuar os conflitos entre gerações, identificando, inclusive, algumas diferenças-chave entre as formas como filhos e filhas são socializados para a sucessão (DUMAS, 1998; IANNARELLI, 1992). Quando comparadas com seus irmãos do sexo masculino, filhas gastariam menos tempo na empresa, desenvolveriam menos qualificações e seriam encorajadas menos freqüentemente a ingressar no negócio familiar. Ainda que o pouco tempo de socialização prévia na empresa tenha motivado algumas queixas entre as entrevistadas, não foi reportada diferença de tratamento entre irmãos e irmãs nesse processo. Uma possível conseqüência do pouco tempo de socialização prévia e da entrada não planejada na empresa foi um tempo maior para que essas mulheres se sentissem realmente engajadas no negócio.

Ah, demorou bastante tempo. Não sei dizer quanto, mas demorou bastante para eu ter certeza do que eu estava fazendo e as pessoas também confiarem no que eu estava fazendo; terem certeza que a minha resposta está certa, que eu tomei a decisão certa. Isso demora, demorou. (E3)

No começo, para mim foi um pouco estranho porque eu achava que as coisas demoravam um pouco para acontecer. Eu estava acostumada com o meu dia-a-dia corrido, mas aqui eu tinha que ter mais paciência, tinha que começar a entender, eu tinha que ler.... (E6)

Eu gostava muito de trabalhar com livro, sempre gostei, mas foi um processo dolorido. O processo de junção com a família, de trabalhar junto com a família, de conversar com a família, de encontrar seu espaço, de entender seu valor, as limitações que são da empresa, as limitações que são da família... Tem limitações, mistura, não tem como. (E2)

\section{A relação pai e filha/o pai mentor}

Ao contrário dos filhos sucessores de empresas familiares que lutam por seu espaço estabelecendo um distanciamento das gerações anteriores, a literatura ressalta que as mulheres parecem precisar da companhia, da presença e da constante aceitação de entes queridos para formar sua identidade (DUMAS, 1998). A figura do pai mentor em empresas familiares seria, portanto, fundamental para elas. De fato, todas as nossas herdeiras dizem ver seus pais como os mentores de sua vida profissional, com exceção das entrevistadas E2 e E7, cujos pais nunca trabalharam na empresa da família.

Um fato curioso foi que, apesar da entrevistada E2 ter a mãe como a pessoa da geração imediatamente anterior na empresa, ela apontou o avô materno como seu verdadeiro mentor. Também é interessante observar o respeito e o conceito de mentor sempre predominantes no universo masculino, parecendo indicar a cultura 
patriarcal presente no nosso país (HOFSTEDE, 1994; MACEDO et al, 2004). Além de apontá-los como mentores, as entrevistadas que trabalham com seus pais demonstraram também forte admiração profissional por eles. Respeito, orgulho e carinho foram outros sentimentos muito presentes nos discursos.

Como eu confio muito na capacidade dele, eu tento ver aonde ele tem a razão dele e onde eu posso acrescentar alguma coisa. Realmente, é muito difícil acontecer de ele estar errado totalmente e eu estar totalmente certa. (E3)

Eu paro e fico olhando, e meu pai é um ótimo profissional. Não é porque é meu pai, não, parece demagogia, coisa de filha... Se eu tiver um "mindinho" da experiência que o meu pai tem, eu já me dou por satisfeita. (E5)

Acho que fui muito direcionada pelo meu pai. Eu sempre tive dúvida entre fazer alguma coisa na área financeira - administração ou economia - ou veterinária ou biologia. Meu pai se formou em economia; então, eu sempre via meu pai e, quando a gente era criança, a empresa deles era muito grande... Então, quando eu era mais nova, eu tinha vontade de trabalhar um dia com o meu pai. (E6)

A exagerada admiração pelo pai verificada nas entrevistas poderia sugerir que essas mulheres apresentam o perfil da "protetora do pai", identificado na bibliografia (DUMAS, 1998). Entretanto, ainda que todas as entrevistadas tenham demonstrado carinho e respeito pelo pai, a maioria citou melhorias ocorridas nas empresas por iniciativa delas, o que revela uma saudável autoconfiança e vai de encontro ao perfil mencionado.

Eu não tinha muita experiência, mas eu tinha uma bagagem acadêmica maior do que as pessoas que estavam conversando comigo. Eu estava mais atualizada ou estava mais em contato com o mercado do que as pessoas que estavam trabalhando comigo... Eu acabei mudando vários fornecedores da área administrativa, melhorando vários contratos... (E4)

Por outro lado, detectou-se uma proteção maior do pai para a filha, confirmando os estudos que apontam que alguns pais experimentam emoções conflitantes quando pensam em colocar suas filhas como suas sucessoras (HOLLANDER; BUKOWITZ, 1990 apud DUMAS, 1998; VERA; DEAN, 2005). Algumas entrevistadas contaram que têm horários de trabalho mais leves e flexíveis, enquanto outras revelaram terem sido limitadas ao desempenho de funções mais operacionais, confirmando assim a idéia de que os pais preferem preservar as filhas de algumas tarefas desgastantes exigidas de quem comanda um negócio.

Acho que ele me protege mais do que ao meu irmão. Acho que até por ser mulher... os homens acham que mulher é mais ingênua, mais boba... Eu vejo que ele tem mais paciência comigo do que ele teria com o теи irmão. (E1)

Então, existe da parte deles uma preocupação comigo porque eles querem me poupar porque eu não posso fazer o trabalho pesado... e eles ficam me poupando, ficam em volta de mim, me poupando... A empresa começa às 4 horas da manhã, eu não vou 4 horas da manhã, quem vai é o meu pai. (E3)

Todo dia a gente tem que estar lá de 8 às 18h, mas eu não chego 8h. Ele acorda, se arruma e sai. Quando ele está saindo, ele me chama e eu levanto com mais calma porque eu sei que ele foi e que ele abriu [a empresa]. (E5)

Eu não vou para o Maranhão sozinha. Oи eu vou com meu pai ou vou com meu irmão. Eu não me sinto à vontade sozinha. Esse mundo de cana é campo, é homem só trabalhando no campo, um monte de trabalhador rural... eu não me sinto à vontade de andar por lá sozinha. (E6)

\section{0 papel dos membros invisíveis da família/a relação mãe e filha}

A literatura sugere que a mulher proprietária de negócios ancora-se fortemente no apoio psicológico e emocional de familiares e amigos, chamados de "membros invisíveis" (DUMAS, 1998; DONOVAN; BRADT, 1990). Consultadas sobre o papel de familiares que não trabalham na empresa na formação de suas idéias, a 
maioria das entrevistadas indicou importância maior da mãe e do marido ou namorado nas discussões em casa sobre eventos ocorridos no escritório.

Já no que diz respeito ao triângulo mãe-pai-filha, que, segundo alguns pesquisadores (HOLLANDER; BUKOWITZ, 1990 apud DUMAS, 1998), ocorreria quando houvesse ciúmes das filhas por parte das mães que não trabalham com elas na empresa familiar, o mesmo não foi identificado entre as entrevistadas. Entretanto, a influência indireta das mães esteve sempre presente; às vezes, indicando certo ciúme.

Ela não vai lá, mas ela acaba ajudando em casa, sim. Porque se a gente precisa de alguma coisa, a gente liga para casa e ela sempre nos auxilia... Mas ela sabe quem são os funcionários. Se a gente tem algum problema com algum deles, ela acaba sabendo, porque a gente fala sobre isso, e ela participa. Como não há muita rotatividade, ela conhece os funcionários. E também, além disso, ela sempre participa das festas e das confraternizações da empresa. (E3)

Ela sentiu muito ciúme, principalmente, de mim com meu pai. Ela já sentia antes de eu vir para cá. Às vezes, ele tem coisas para comentar comigo e ela está perto, e ele não comenta com ela porque é assunto de trabalho, assunto que eu vou entender e ela não vai, daí ela começa a ficar emburrada. (E4)

Ainda de acordo com a literatura, quando mãe e filha trabalham juntas, a mãe seria muito controladora e a filha seria muito crítica em relação à sua mãe, se há problemas de confiança não resolvidos na adolescência (RESNICK, 1994; VERA; DEAN, 2005).

Três entrevistadas trabalham junto com suas mães, e apenas uma trabalha com o pai e a mãe ao mesmo tempo. Apenas uma entrevistada reportou que a mãe seria muito controladora e dificultava um processo harmônico de sucessão. As outras duas, apesar de reportarem um bom relacionamento com suas mães, atribuíam à figura paterna (seja do pai ou do avô) seu "porto seguro", sua ancoragem.

Por exemplo, ela chegou a um ponto, assim: "Eu não quero mais saber de nada, está tudo nas suas mãos". Aí, eu falei que, se estava tudo nas minhas mãos, então ia acabar com o aluguel de toalhas. "Ah não, mas eu sou a sócia majoritária... Ainda sou sócia e eu tenho que decidir também, e eu não quero"... (E7)

\section{Perda dos contatos sociais/tipos de laços sociais}

As entrevistas confirmam que a redução dos contatos externos é um ponto negativo da empresa familiar, indo ao encontro da tendência identificada por Lyman (1988) de que, ao renunciar a empregos em outras empresas, as mulheres deixam de contar com redes independentes de colegas de trabalho e contatos para negócios.

Eu já sou muito ligada à minha família e vim trabalhar com a minha família. Então, o seu círculo se fecha cada vez mais. Tem épocas que realmente... Agora já melhorou, mas tinha época que dava um desespero esse negócio. Sair, conhecer gente diferente.... (E6)

Eu vejo minhas amigas: "Vou sair com o pessoal do trabalho"; "A gente vai tomar um chopinho com o pessoal do trabalho" ou "Meus amigos do trabalho vêm aqui em casa"... E eu não tenho isso... Não saio para tomar chope com os funcionários, não chamo eles para virem na minha casa, nunca fui para a casa deles... (E1)

Dá vontade, às vezes, de dar uma guinada, né? "Acho que eu vou trabalhar em outro lugar para ampliar meu círculo de amigos", mas é esporádico. E tem aquela coisa: o meu relacionamento com os funcionários é estritamente profissional. Lá na empresa, nós temos um refeitório próprio e eu não saio para almoçar. Então, eu sinto uma necessidade de sair porque eu fico o dia inteiro na empresa. (E3)

A queixa das entrevistadas emergiu sempre do ponto de vista de suas vidas pessoais. Reduzir os contatos profissionais de fora do círculo da família criaria uma privação de programas sociais, aqui, representados 
muitas vezes pelo "chope com o pessoal do trabalho". Para melhor compreender essa crítica, deve ser lembrado que não se ganha apenas independência financeira trabalhando fora. Há todos os benefícios paralelos: atualização intelectual, troca de experiências com colegas, ganho de autoconfiança e distração, entre outros. Ao trabalharem na empresa de suas famílias, essas mulheres deixam de contar com o benefício da amizade natural entre colegas, uma vez que o relacionamento com funcionários não pertencentes à família tende a se limitar ao âmbito profissional.

Por outro lado, diversas entrevistadas ressaltaram o lado positivo desses laços sociais internos, também confirmando a literatura no que diz respeito à tendência da empresa familiar de proporcionar relacionamentos mais seguros, de longo prazo, ancorados em princípios de confiança e lealdade. Esses relacionamentos gerariam um ambiente de trabalho único, que inspira um maior cuidado e lealdade por parte dos funcionários, os quais passam a ser vistos como "parte da família" dos patrões (HABBERSHON; WILLIAMS, 1999).

E o clima é um clima de descontração. As pessoas estão rindo, conversando. Não é um clima tenso de trabalho. É um clima bem harmonioso. Ele (meu pai) é muito democrático; sempre foi em casa e é lá. Nós somos muito família e lá também. A gente tenta fazer a empresa parecer mesmo uma família. É a mesma coisa. (E3)

\section{Administração feminina versus administração masculina}

De acordo com Gelim (1998), características consideradas masculinas incluem o espírito competitivo, a independência, a decisão e a autoconfiança; enquanto características femininas são normalmente a emotividade, a sociabilidade, a compreensão, o cuidado e o carinho. As mulheres entrevistadas se percebem mais organizadas, sensíveis e detalhistas do que seus pares do sexo masculino.

Eu sou mais organizada, sou menos paciente e sou mais coração mole também. Assim, tipo, por ser mulher e estar nessa região pobre, eu ainda não me acostumei a olhar o trabalhador rural trabalhando no campo debaixo de um sol de $40^{\circ}$... Dá embrulho no estômago, mesmo. Eu já fui para lá para o Maranhão umas 12 vezes, nesse um ano e meio, e eu volto mexida, sempre. Eu tenho pena... E para ele [pai] é a coisa mais natural do mundo. Ele já acostumou, está no sangue dele [...] (E6)

Os relatos das entrevistadas indicam ainda a percepção de si próprias como mais cautelosas, precavidas, confirmando assim características identificadas por estudiosos como inerentes ao perfil feminino, em contraponto ao estereótipo do perfil masculino, associado ao empreendedor de sucesso visto como independente, persistente, que tem energia, é autoconfiante e decidido (GELIN, 1998; THIRY-CHERQUES; PIMENTA, 2003).

Eu realmente sou diferente do meu pai. Ele é muito ativo, muito dinâmico, muito rápido... Eu sou muito mais cautelosa, fazendo a conta para ver se vale à pena alguma decisão. Enquanto ele já fez de cabeça, eu estou lá na máquina... Meu pai diz que é experiência e que, com o amadurecimento profissional, eu vou ficar assim também... (E3)

Esse perfil estereotipado do empreendedor de sucesso está, aparentemente, enraizado nessas mulheres e aparece em seus discursos através do receio de que a chave do sucesso da empresa esteja relacionada ao perfil mais agressivo e tomador de risco de seu pai, caracterizando a angústia do processo sucessório vivida por elas.

Na verdade, eu não sou muito empreendedora, não. Isso é uma coisa que eu fico me comparando com o meu pai e com o meu marido. Eu tenho muito menos vontade de [sic] tomar risco do que eles. Sabe, eu gosto de ter uma empresa esquematizada e ir ganhando dinheiro; eles gostam de "Está esquematizado? Então, vamos arrumar outra coisa, outro problema". Isso me deixa um pouco histérica, não é muito o meu perfil. Então, não sei como isso funciona depois da vida da primeira pessoa [depois da morte do fundador], se é uma pessoa que não tem tanta tendência a [sic] tomar risco, e eu não tenho mesmo. Acho que eu consigo conviver muito bem com ele, mas alguém tem que 
criar ele para mim. Alguém tem que criar o problema e eu administro. Se eu tiver que criar os problemas, daqui a pouco, não sei muito bem como isso vai ser. (E4)

Foi notado ainda que a possibilidade de dividir com irmãos ou primos o controle da empresa atenuava a angústia dessas mulheres. Embora haja na literatura muita referência a conflitos entre familiares na disputa pelos cargos de maior poder, neste estudo, a existência de múltiplos herdeiros surgiu como ponto positivo, pois criaria a possibilidade de complementar o perfil ideal de comando do negócio. Vale comentar, entretanto, que o estágio sucessório pode ser decisivo na forma como os herdeiros se vêem. Como todas as entrevistadas se encontravam no estágio inicial de sucessão, é mais natural que ainda não tivesse ocorrido nenhum conflito entre os pares de uma geração.

Temos (eu e meus irmãos) uma diferença de idade muito pequena, dois anos cada um. Então, a gente cresceu junto, fez tudo junto, nossos amigos são os mesmos porque a gente sempre saiu junto... Então, a gente tem uma cumplicidade muito grande, e isso facilita tudo. Porque a gente não tem barreiras para dizer o que a gente está em dúvida. Se tem alguma coisa que o meu irmão possa me ajudar... acho que ele é a pessoa de mais fácil acesso que eu poderia ter. (E3)

Hoje em dia, eu diria que sou eu e o meu irmão [os potenciais sucessores], porque a gente se complementa muito bem. Eu gosto de planejamento, de trabalho interno. Eu gosto da área financeira, eu gosto de planejar, eu gosto de sentar e estudar. E ele gosta mais do lado comercial, mais político. (E6)

Se, por um lado, há muitos estudiosos que defendem exageradamente o perfil dos fundadores, há também outros que afirmam que a semente do fracasso da sucessão se encontraria justamente no empreendedor de primeira geração. Características como o medo da morte, a relutância em abdicar do controle e do poder, a incapacidade de escolher entre os filhos, o preconceito contra o planejamento e o medo da perda da identidade empresarial são citadas como muito comuns entre os fundadores e como entraves ao processo sucessório (LEACH, 1998). Entre as nossas entrevistadas, as pertencentes à segunda geração confirmaram que seus pais são centralizadores e têm dificuldade de renunciar ao poder.

Ainda não existe nenhum plano [sucessório], porque meu pai não tem interesse em largar... (risos). Meu pai diz que não quer, que ainda tem uns 20 anos para trabalhar... E ele sente um prazer muito grande em trabalhar... Agora ele não tem interesse em sair e a gente deixa correr, porque, por enquanto, não há uma necessidade. Ele tem um prazer muito grande em trabalhar, e diz: "Não, vão vocês, tirem férias vocês! Eu fico aqui!"... (E3)

Mas aposentar, assim, de ficar em casa, meu pai nunca vai fazer isso... Nem que ele passe lá todo dia de manhã... Meu pai acorda muito cedo, adora acordar cedo, dormir cedo... Mas aposentar de ficar em casa, ele jamais vai fazer isso. Vai morrer lá dentro da fábrica. Nunca vai largar tudo... Não vai fazer isso. (E1)

\section{Equilibrio vida/trabalho}

Com relação a esse tema, os resultados das entrevistas confirmam o estudo de Hill et al (2001), segundo o qual aqueles que tinham flexibilidade de local e de carga horária apresentavam melhor equilíbrio, conseguindo trabalhar por mais horas até que a carga de trabalho influenciasse negativamente a vida pessoal. As conclusões também coincidem com as de Scandura e Lankau (1998) no sentido de que mulheres que trabalhavam em organizações com horário flexível apresentavam maior nível de comprometimento organizacional e estavam mais satisfeitas do que aquelas com turnos fixos definidos.

Por outro lado, apesar da literatura afirmar que o sucesso em atingir um saudável equilíbrio entre vida pessoal e profissional na empresa familiar seria um pouco controverso (VERA; DEAN, 2005; CADIEUX, LORRAIN; HUGRON, 2002), as herdeiras entrevistadas encaram bem o fato de que eventualmente tenham que trabalhar fora do expediente comercial, reconhecendo positivamente essa liberdade de carga horária. 
Tem a flexibilidade, sem dúvida. Mas a flexibilidade implica também no trabalho em final de semana. É flexível de um lado, assim... "Ah, hoje eu vou levar as filhas no médico" e etc. ... mas, se amanhã eu tenho que trabalhar sábado e domingo, eu trabalho; no feriado, eu também vou... (E2)

O lado bom é a flexibilidade. Não tenho um período certo para férias... Se eu precisar viajar amanhã, eu posso porque eu tenho o meu irmão e a minha irmã que vão poder ficar lá e assumir a minha posição. Se eu preciso sair durante o dia para alguma coisa, não tem problema nenhum. Se eu chego mais tarde, também. Existem coisas que talvez possam ser interpretadas como o lado bom ou ruim, depende muito do momento. Eu trago muita coisa para fazer em casa. Como o negócio é próprio, eu trago para fazer aqui. Às vezes, não dá para fazer lá; eu faço em casa. Isso é bom, porque às vezes eu estou de bobeira em casa e posso trabalhar; e isso é ruim porque eu acabo não me desligando... (E3)

Assumindo que existe um "contrato psicológico", conforme proposto por Rousseau (1995), pelo qual cada uma das partes - empresa e empregado - imagina quais serão seus direitos e deveres com a outra, podemos concluir que existe uma troca justa entre a herdeira e a empresa familiar, no que diz respeito ao equilíbrio pessoal e profissional. Fica claro para a mulher que o preço que ela paga por não ter uma cobrança rígida de carga horária é a disponibilidade de seu tempo fora do expediente normal para demandas eventuais.

Eu já trabalhei numa fábrica. Logo que eu me formei, eu trabalhei como estilista de uma fábrica. Eu trabalhava meio expediente e tinha ponto, tinha que bater ponto. Eu odiava. Não me adaptei mesmo. Aqui, é assim: um dia eu tenho que chegar cedo porque tenho cliente cedo, mas tem dia que eu não tenho cliente de manhã e, então, eu posso resolver minhas coisas de casa. Eu tenho essa flexibilidade. Agora então, morando aqui, posso dar uma fugida, almoçar, voltar... (E7)

Ainda nesse sentido, vale destacar que o acordo de flexibilidade versus disponibilidade não é privilégio de empreendimentos familiares. Entretanto, os custos desse novo contrato psicológico são aparentemente menores para os membros da família. Isso se mostra claro no caso das nossas entrevistadas, uma vez que o proprietário é normalmente seu pai ou avô e, por isso, compreende e permite mais facilmente uma flexibilidade de tempo e dedicação para que elas equilibrem suas demandas pessoais e profissionais. Além disso, o "comprometimento com seu próprio desempenho" pode ser mais prazeroso quando os ganhos do trabalho vão diretamente para o bolso da família. Sem falar da ausência da ameaça de demissão (que reduz as angústias) e dos ganhos com laços sociais mais fortes e de longo prazo, já citados.

Ainda que a literatura aponte a possibilidade de melhor equilibrar suas atividades profissionais e sua vida familiar como um importante motivador para o ingresso da mulher na empresa de sua família (CROMIE; SULLIVAN, 1999), nenhuma entrevistada afirmou abertamente que esse equilíbrio tenha sido realmente decisivo em sua escolha. Conforme já visto, a opção de entrada foi pautada, em sua maioria, pela necessidade de ajuda ao pai/mãe e por falta de opções mais atrativas. Outro ponto interessante detectado nas entrevistas foi a diferença de equilíbrio entre a primeira e a segunda geração (pai/mãe e a filha), em relação ao qual as entrevistadas afirmaram conseguir se desligar dos negócios mais facilmente do que seus pais, quando saem do escritório ou quando tiram férias.

Eu me despeço da reunião, levanto antes, vou lá desligar meu computador e falo: "Tchau, existe vida pós-trabalho!"... Eu vou malhar, vou ao shopping, vou encontrar minhas amigas... 'Tchau, estou indo!'... E aí todo mundo levanta, vai embora... Não sei se isso é gênero, de homem e mulher. A mulher se desliga mais fácil. (E4)

Uma possível explicação para essa diferença de atitude em relação ao equilíbrio vida/trabalho é apresentada por uma das entrevistadas. Estaria baseada no duplo papel desempenhado pelas mulheres que, além de profissionais, também precisam ser donas de casa quando voltam para casa. Já o homem poderia continuar pensando no trabalho, mesmo em casa, uma vez que a esposa é que estaria cuidando dos afazeres domésticos.

Eu vejo, na minha casa, meu pai chega em casa e ele não sabe se a empregada veio, se não veio, se tem comida... Não sabe nada... Ele chega lá, toma banho, lancha, e vai dormir... A mulher tem que 
chegar em casa e ver se a empregada veio, se tem material de limpeza, se está faltando isso, se a criança comeu, se não comeu, se foi para a escola... Então, eu acho que a mulher consegue administrar várias coisas ao mesmo tempo que o homem não conseguiria administrar. (E1)

Outra razão para a interferência menor do trabalho na vida pessoal da maioria das entrevistadas poderia ser a de que o empreendedor de primeira geração carrega um perfil mais centralizador e, portanto, não consegue se desligar. A herdeira em fase inicial de sucessão ainda não teria se envolvido o suficiente para sentir-se tão engajada a ponto de não conseguir se desligar. Assim, poderíamos vislumbrar como tendência futura o fato de que a herdeira, ao caminhar para o estágio final da sucessão, venha a assumir mais responsabilidades no negócio, passando, com isso, a encontrar mais dificuldade em equilibrar vida profissional e pessoal.

\section{Conclusões}

O maior número de mulheres com bom preparo educacional, capazes de ocupar posições gerenciais, possibilitou o crescimento da presença feminina no processo sucessório de empresas familiares. Tal crescimento também estaria associado a outros fatores verificados no país, como a receptividade da cultura brasileira ao modelo familiar de gestão e a forte concentração de poder e capital nas mãos de poucas famílias.

Este artigo analisou as percepções de sete herdeiras de empresas familiares do Rio de Janeiro sobre as principais questões relativas ao estágio inicial da sucessão, em especial, sobre a preparação para o ingresso na organização, a criação de sua identidade como sucessora, o relacionamento com o fundador e o equilíbrio vida/trabalho.

Percebeu-se, tendo por base este estudo, que não há um planejamento formal de sucessão das herdeiras com antecedência suficiente que lhes garanta uma clareza em relação às suas responsabilidades, aos caminhos que precisam percorrer até a sucessão ou à sua identidade profissional na firma familiar. Mesmo nos casos em que a herdeira é âncora - ou seja, pertence a famílias com apenas descendentes mulheres ou com poucos homens e sobre quem a responsabilidade de liderar a empresa esteve presente desde a infância -, a entrada não foi discutida com antecedência.

Seja consequiência do receio por parte da geração anterior de que o planejamento formal pressione demasiadamente a filha a optar pela entrada na empresa, seja consequiência de uma discriminação antecipada, a inexistência de um plano de entrada traz alguns malefícios. Em especial, destaca-se o fato da filha demorar a se sentir engajada na empresa, em ganhar autoconfiança e em encontrar seu espaço. Por outro lado, a socialização prévia da herdeira no ambiente da empresa familiar atenuaria os efeitos dessa ausência de planejamento formal: quanto mais exposta previamente ao ambiente do negócio, mais confortável a filha se sentiria quando finalmente entrasse na organização.

Apesar de sofrer com a angústia da entrada não planejada, a herdeira tem a vantagem de contar com seu pai como mentor. O mentor é, de fato, figura essencial na busca por seu espaço e na formação de sua identidade. Essas mulheres precisam se preocupar, no entanto, com o papel de "protetoras do pai", apontado por Dumas (1990 apud DUMAS, 1998) como prejudicial à sucessão saudável. Devem lutar para ganhar seu espaço, não apenas seguindo os passos da antiga geração no poder, mas criando um espaço de ação próprio.

Nessa busca, precisam atentar também para o excesso de proteção que costumam receber dos pais. Há claramente pontos de discriminação de gênero, com delimitações distintas de tempo e espaço femininos e masculinos. Alguns horários de trabalho, alguns locais e algumas atividades não são permitidos às filhas sob o pretexto da proteção.

Os efeitos negativos de redução das redes de contato para herdeiras em empresas familiares foram confirmados nos discursos das entrevistadas. Assim, haveria de fato um risco delas não explorarem comportamentos não tradicionais, já que a limitação das redes tenderia a restringir a diversidade desses comportamentos e a reforçar a estabilidade e a previsibilidade no ambiente de trabalho. Esse risco, no entanto, parece depender do perfil 
dessa mulher e de suas experiências profissionais ou acadêmicas - cursos de extensão, por exemplo - que lhe permitissem uma maior ou menor rede de contatos.

Além disso, detectou-se que, se trabalhar no negócio familiar representa abdicar do dinamismo e da diversidade do mercado em geral, significa também se envolver num trabalho interessante, desafiador e satisfatório. Significa trabalhar para si mesma ou para outro membro da família, em vez de ser empregada de terceiros. Além disso, proporciona um estilo de vida confortável, em que o suporte da família cumpre um papel essencial de apoio moral, solidariedade e amor. Outra interessante vantagem é a possibilidade de ancoragem em laços sociais mais fortes e de confiança, típicos de uma relação de longo prazo, onde a pessoa tem a oportunidade de acompanhar toda a história da empresa, sem a ameaça das demissões.

O processo sucessório, entretanto, não se inicia sem angústias. A herdeira, em geral, sente falta do perfil empreendedor da primeira geração, com sua típica rapidez de raciocínio, coragem para assumir riscos e larga experiência. Ela se sente mais sensível, mais detalhista e cautelosa que seus pares do gênero oposto e teme que sua gestão não corresponda às expectativas. Quando possui irmãos ou primos trabalhando em conjunto, sentese mais tranqüila, pois haveria a possibilidade de complementar o perfil ideal de comando do negócio.

A cautela feminina, no entanto, não deve ser confundida com falta de coragem, uma vez que representa um ato de cuidado e atenção que visa à manutenção de redes de relacionamentos. Nesse sentido, a visão de sucesso de empresas comandadas pelas herdeiras precisaria ser aprofundada com cuidado para evitar que parâmetros de êxito tipicamente masculinos fossem aplicados para medir negócios guiados por mentes femininas, pautadas por diferentes conceitos de tempo, espaço, poder e ética.

Maior do que o problema da diferença entre administração feminina e masculina é a dificuldade da primeira geração descentralizar o poder e se afastar do negócio. Ficou confirmado o típico desejo da imortalidade do fundador que, além de não ter planos para se aposentar, não consegue tirar férias e nem se desligar do trabalho nos fins de semana.

Para a sucessora, o desligamento do mundo profissional é mais rápido, o que atenua os custos ligados ao equilíbrio vida/trabalho em empresa própria. A flexibilidade de carga horária é trocada pela maior disponibilidade para o trabalho e pelo envolvimento total com assuntos do negócio. A troca é feita através de um contrato psicológico claro e encarado como justo pela herdeira.

Ainda que o equilíbrio saudável entre lado pessoal e profissional não tenha sido o motivador principal de entrada na empresa, ele representa um grande benefício para a herdeira, uma vez que as mulheres continuam a fazer a maior parte do trabalho da casa, independentemente de seu status, de suas horas de trabalho ou de sua remuneração. Assim, um ponto naturalmente valorizado por elas é a possibilidade de flexibilização das horas e dos locais de trabalho. Não se deve esquecer, no entanto, que o equilíbrio não é consequiência apenas dessa flexibilização. Ele surge também do fato de que é menos custoso abdicar do tempo pessoal quando se sabe que o fruto do trabalho extra retornará em forma de um maior patrimônio para a família. 


\section{Referências}

BARBIERI, Elisa Morganti. A batalha das herdeiras na empresa familiar. Porto Alegre: Sagra, 1997.

BARNES, L. Incongruent hierarchies: daughters and younger sons as company CEO's. Family Business Review, v.1, issue 1, p.9, March 1988.

BERNHOEFT, R.; GALLO, M. Governança na empresa familiar. 4.ed. Rio de Janeiro: Campus, 2003.

BETHLEM, A. Gestão de negócios: uma abordagem brasileira. Rio de Janeiro: Campus, 1999.

CADIEUX, L.; LORRAIN, J.; HUGRON, P. Succession in women-owned family business: a case study. Family Business Review, v.15, n.1, p.17-30, 2002.

CHANDLER, Michele. More women stepping into roles in family business. San Jose Mercury News. Com, CA, 5 Sept. 2004. Disponivel em: <http://www.usfca.edu/fbrc/More_women_in_family_bus.pdf> Acesso em: 6 out. 2007.

COLE, P. Women in family business. Family Business Review, v.10, issue 4, p.353, Dec. 1997.

COSTA, Armando João Dalla. Sucessão e sucesso nas empresas familiares. Curitiba, CMDE/UFPR. 2005. Disponivel em: <http://www.economia.ufpr.br/publica/textos/2005/Armando\%20dala\%20costa.pdf> Acesso em: 6 out. 2007.

CRESWELL, J. Research design: quantitative, qualitative and mixed methods approaches. 2nd ed. [S.I.]: Sage Publications, 2003.

CROMIE, S.; SULLIVAN, S. Women as managers in family firms. Women in Management Review, v.14, n.3, 1999.

CURIMBABA, F. The dynamics of women's roles as family business managers. Family Business Review, v.15, issue 3, p.239, Sept. 2002.

DAVEL, E.; COLBARI, A. Organizações familiares: desafios, provocações e contribuições para a pesquisa organizacional. In: XXVII ENCONTRO DA ASSOCIAÇÃO NACIONAL DE PÓS-GRADUAÇÃO E PESOUISA EM ADMINISTRAÇÃO - ENANPAD, 2003, Atibaia/ SP. Anais... Rio de Janeiro: ANPAD, 2003. 1 CD-ROM.

DONNELEY, Robert. A empresa familiar. São Paulo: Abril-Tec, 1976.

DONOVAN, J; BRADT, C. The power of invisible women in the family business. Family Business Review, v.3, issue 2, p.153, June 1990.

DUMAS, C. Women's pathways to participation and leadership in the family-owned firm. Family Business Review, v.11, issue 3, p.219, Sept. 1998.

ÉLVAREZ, E.; SINTAS, J.; GONZALVO, P. Socialization patterns of successors in first to second generation of family businesses. Family Business Review, v.15, issue 3, p.189, Sept. 2002.

GELIN, M. The importance of gender in starting and managing a small business. 1998. Disponivel em: <http://www.houstonpsychiatry.org/1119201819/entrepreneur\%20womne.htm>. Acesso em: 3 out. 2007.

GREEHAUS, J. H.; BEUTELL, N. J. Sources of conflict between work and family roles. Academy of Management Review, v.10, p.76-88, 1985.

GRZYBOVSKI, D.; BOSCARIN, R.; MIGOT, A. Estilo feminino de gestão em empresas familiares gaúchas. RAC - Revista de Administração Contemporânea, v.6, n.2, p.185-207, maio/ago. 2002.

HABBERSHON, T.; WILLIAMS. M. A resource-based framework for assessing the strategic advantage of family firms. Family Business Review, v.12, issue 1, p.27, Mar. 1999.

HABERMAN, H.; DANES, S. M. Father-daughter and father-son family business management transfer comparison: family Firo model application. Family Business Review, v.20, issue 2, p.163-184, June 2007.

HANDLER, W. Succession in family business: a review of the research. Family Business Review, v.7, issue 2, June 1994.

HILL, E. J. et al. Finding an extra day a week: the positive influence of perceived job flexibility on work and family life balance. Family Relations, v. 50, n.1, p.49-58, 2001. 
HOFSTEDE, G. Cultures and organizations: cultural cooperation and its importance for survival. London: McGraw-Hill International, 1994. IANNARELLI, C. The socialization of leaders: A study of gender in family business. Unpublished doctoral dissertation, University of Pittsburgh, 1992.

IWAKURA, Fábio Luís. Ai vêm elas!! Via6, 7 mar. 2007. Disponível em: <http://www.via6.com/artigo.php?aid=6564> Acesso em: 6 out. 2007.

LANSBERG, I. The succession conspiracy. Family Business Review, v.1, issue 2, p.119, June 1988.

LEACH, P. Guia da empresa familiar. Rio de Janeiro: Xenon, 1998.

LETHBRIDGE, Eric. Tendências da empresa familiar no mundo. Revista do BNDES, n.7, jun. 1997. Disponível em: <http://www.bndes.gov.br/conhecimento/revista/rev707.pdf> Acesso em: 8 out. 2007.

LONGENECKER, Justin G.; MOORE, Carlos W.; PETTY, J. William. Administração de pequenas empresas: ênfase na gerência empresarial. São Paulo: Makron Books, 1997.

LYMAN, Amy R. Life in the family circle. Family Business Review, v.1, issue 4, p.383, Dec. 1988.

MACEDO, Kátia et al. 0 processo sucessório em organizações familiares e a exclusão da mulher. Psicologia \& Sociedade, v.16, n.3, p.6981, set./dez. 2004.

MACHADO, Roberta Magalhães da Cruz. Pesquisa de Campo para Dissertação de Mestrado. Rio de Janeiro: Coppead/UFRJ, 2006. Disponivel em: http://www2.coppead.ufrj.br/port/index.php?option=com_docmanctltemid=204\&task=cat_view\&tgid=46\&tdir=DESCCtorder=datectlimit=1 0\&tlimitstart=70> Acesso em: 6 out. 2007.

RESNICK, R. Mother-daughter teamwork - businesses run by mothers and daughters. Nation's Business. Dec. 1994. FindArticles.com, 26 May. 2008. Disponivel em: <http://findarticles.com/p/articles/mi_m1154/is_n12_v82/ai_15920914> Acesso em: 6 out. 2007.

ROUSSEAU, Denise M. Psychological contract in organizations. Thousand Oaks: Sage, 1995

SCANDURA, T.; LANKAU, M. Relationships of gender, family responsibility and flexible work hours to organizational commitment and job satisfaction. Journal of Organizational Behavior, v.18, issue 4, 1998.

SHARMA, P. An overview of the field of family business studies: current status and directions for the future. Family Business Review, v.7, issue 1, Mar. 2004.

TEIXEIRA, Z. As mulheres e o mercado de trabalho. Publicado em 9 set. 2005. Universia: Portal de Educação para Estudantes Universitários. Disponivel em: <http://www.universia.com.br/html/materia/materia_daba.html>. Acesso em: 3 out. 2007.

THIRY-CHERQUES, H.; PIMENTA, R. Condição feminina e percepção dos valores morais no nível técnico e gerencial das organizações brasileiras. In: XXVII ENCONTRO DA ASSOCIAÇÃO NACIONAL DE PÓS-GRADUAÇÃO E PESOUISA EM ADMINISTRAÇÃO - ENANPAD, 2003, Atibaia/ SP. Anais... Rio de Janeiro: ANPAD, 2003. 1 CD-ROM.

VERA, C.; DEAN, M. An examination of the challenges daughters face in family business succession. Family Business Review, v.18, issue 4, p.321, Dec. 2005.

\section{Notas}

${ }_{1}^{1}$ Donneley, 1976; Lodi, 1999 (apud COSTA, 2005).

${ }^{2}$ Levantamento do Centre for Family Enterprise, tratando de empresas familiares na União Européia (apud LETHBRIDGE, 1997).

${ }^{3}$ Cohen, 1998; Jones e Gautschi, 1988; Ruegger e King, 1992; e Shaub, 1994 (apud THIRY-CHERQUES e PIMENTA, 2003).

${ }^{4}$ Starr e Yudkin, 1996 (apud DUMAS, 1998).

${ }^{5}$ Dumas, 1992; e Salganicoff, 1990 (apud DUMAS, 1998).

${ }^{6}$ Salganicoff, 1990 (apud DUMAS, 1998).

${ }^{7}$ Keating e Little, 1997 (apud DUMAS, 1998).

${ }^{8}$ Iannarelli, 1992 (apud DUMAS, 1998). 